Original

\title{
Treatment of high saline textile wastewater by activated sludge microorganisms
}

\author{
Hanieh Mirbolooki $^{\mathrm{a}, \mathrm{b}, *}$, Reza Amirnezhad ${ }^{\mathrm{b}}$, Ali Reza Pendashteh ${ }^{\mathrm{c}}$ \\ ${ }^{a}$ Academic Centre for Education, Culture and Research (ACECR), Environmental Research Institute, Rasht, Iran \\ ${ }^{\mathrm{b}}$ IAU, Tonekabon Branch, Tonekabon, Iran \\ ${ }^{\mathrm{c}}$ University of Guilan, Rasht, Iran
}

Received 18 April 2016; accepted 23 January 2017

\begin{abstract}
Textile wastewater is a combination of various chemicals and different types of dyes and has a salty nature. In this study, an SBR (sequencing batch reactor) was used to treat synthetic and real textile wastewaters in a $24 \mathrm{~h}$ cycle time. Remazol Brilliant Blue $\mathrm{R}$, a reactive dye, was used as the model dye. Dye concentrations ranged from $125 \mathrm{mg} / \mathrm{L}$ to $500 \mathrm{mg} / \mathrm{L}$, and TDS (total dissolved solids) concentrations ranged from $1000 \mathrm{mg} / \mathrm{L}$ to $10,000 \mathrm{mg} / \mathrm{L}$ in synthetic wastewaters. For the highest dye concentration $(500 \mathrm{mg} / \mathrm{L})$ with low TDS, an $80.71 \%$ COD removal efficiency was obtained; at a TDS concentration of $5000 \mathrm{mg} / \mathrm{L}$, a $59.44 \%$ COD removal efficiency was obtained. When the TDS concentration of wastewater was raised to $10,000 \mathrm{mg} / \mathrm{L}$, COD removal decreased to $14.92 \%$ and reductions in MLSS (mixed liquor suspended solids) and MLVSS (mixed liquor volatile suspended solids) concentrations were observed. According to the results, increasing the TDS concentration of wastewater up to $5000 \mathrm{mg} / \mathrm{L}$ did not affect COD removal efficiency of the activated sludge microorganisms in the treatment system.

(C) 2017 Universidad Nacional Autónoma de México, Centro de Ciencias Aplicadas y Desarrollo Tecnológico. This is an open access article under the CC BY-NC-ND license (http://creativecommons.org/licenses/by-nc-nd/4.0/).
\end{abstract}

Keywords: Saline wastewater treatment; Sequencing batch reactor; Activated sludge microorganisms

\section{Introduction}

The textile industry is one of the largest sources of contaminant wastewater, because it uses high volumes of water in dyeing, printing, and finishing processes (Nigam, Banat, Singh, \& Marchant, 1996). The most important material consumed by these industries, and thus the most important resulting contaminant, is dye, which is used in large amounts (Nigam et al., 1996). The wastewater from textile and printing industries contain high amount of color and carcinogenic compounds (Quan, Zhang, \& $\mathrm{Xu}, 2015)$; synthetic dyes are resistant to removal because of their aromatic compounds, Remazol Brilliant Blue R (RBBR) the model dye - is a synthetic textile dye which is frequently used in producing polymeric dyes. It is toxic and organo-pollutant dye

\footnotetext{
* Corresponding author.

E-mail address: h.mirbolooki@gmail.com (H. Mirbolooki).
}

Peer Review under the responsibility of Universidad Nacional Autónoma de México. and has an anthraquinon structure (Javaid, Qazi, \& Kawasaki, 2016).

Various chemicals like scattering materials, acids, alkalis, salts, detergents, and oxidations are added during dyeing to improve the dye adsorption and stability of fibers; the most important characteristic of textile wastewater is its salty nature. Cellulosic fibers are the most prevalent textile fibers. When these fibers are placed in water, they are negatively charged because of the ionization of the hydroxyl groups. The most appropriate dyes for these fibers are anionic dyes, such as reactive dyes. An electrical repulsive force between the anionic dye and the fiber causes a reduction in fiber staining (Dodangeh \& Gharanjig, 2012). To solve this problem, $\mathrm{NaCl}$ is used in the dyeing bath. Salt neutralizes the fiber surface charge and causes increased dye adsorption. The additional amount of dye with high concentrations of salt in wastewater increases environmental contamination (Dodangeh \& Gharanjig, 2012). According to different resources, salt range of textile wastewater is varied between 1000 and $10,000 \mathrm{mg} / \mathrm{L}$ (Salvadó, Mas, Menéndez, \& Gracia, 2001; Yurtsever, Calimlioglu, Görür, 
Çnar, \& Sahinkaya, 2016) and the textile industry interns almost 0.2 million tons of salts in the environment per year (Soares et al., 2017).

Wastewater resulting from the dying process is considered the most important contaminant of textile industry wastewater which causes the destruction of organisms, increases BOD concentrations, and decreases the supply of dissolved oxygen in the acceptor water environment (Chaeibakhsh Langroodi \& Abedinzadeh, 2004).

Selecting the appropriate treatment method for wastewater with various chemicals and dyes is very important (Nigam et al., 1996). Different methods, including various chemical, physical, and biological treatments, have been applied for treating textile wastewater. Low dye removal efficiency restricts the application of physical methods such as adsorption and filtration methods (Vandevivere, Bianchi, \& Verstraete, 1998). Chemical oxidation methods make the destruction and degradation of dyestuff molecules possible, but with these methods, various oxidizing agents such as $\mathrm{O}_{3}, \mathrm{H}_{2} \mathrm{O}_{2}$, and $\mathrm{MnO}_{4}$ are used. In addition to being unable to completely remove azo dyes from wastewater (because azo dyes are stable and resistant to degradation), these methods are not economical and even produce large quantities of sometimes toxic sludge (Anjaneyulu, Chary, \& Raj, 2005).

Biological treatment methods have been selected to remove contamination from textile wastewater that contains salt, because they are cost-effective, non-toxic, sustainable, and environmentally friendly (Banat, Nigam, Singh, \& Marchant, 1996; Xiao \& Roberts, 2010).

The sequencing batch reactor is an effective activated sludge process used for treating saline wastewater (Mesquita, Amaral, Ferreira, \& Coelho, 2009). This biological treatment method involves a strong system, simple function, and high flexibility in procedures (Mohan, Rao, Prasad, Madhavi, \& Sharma, 2005).

Equalization, aeration, and clarification can all be achieved using a single batch reactor (SBR). The SBR is appropriate for wastewater treatment applications characterized by low or intermittent flow conditions. Different effluents such as municipal, domestic, hypersaline, tannery, brewery, dairy wastewaters, and landfill leachates can be treated using this biological system (Mace \& Mata-Alvarez, 2002).

SBR is considered a biological system for decolorizing the textile dye including Blue Bezaktive 150, a reactive dye; according to the results, decolourisation rates were obtained in the range of $88-97 \%$ for different volumetric dye loading rates (3-15 g dye $/ \mathrm{m}^{3} \mathrm{~d}$ ) (Khouni, Marrot, \& Amar, 2012).

The color removal efficiency of the SBR system increased when mixed liquor suspended solids (MLSS) were increased. The color removal efficiency of disperse dye treatments (Disperse Blue 60 and Disperse Red 60) was over 98\% at an MLSS of $4000 \mathrm{mg} / \mathrm{L}$; COD and $\mathrm{BOD}_{5}$ removal efficiencies were also quite high (Sirianuntapiboon \& Maneewon, 2012).

According to different studies, high loads of salt (0.5-5\%) decreases the efficiency of biological treatment in wastewater treatment plant (Salvadó et al., 2001); because saline loads reduce the metabolic functions of activated sludge microorganisms (Mahmoud \& Davis, 1979; Woolard \& Irvine, 1995) but, gradually adapting the microorganisms to high saline conditions can help minimizing the effect caused by salt (Bassin, Dezotti, \& Sant'Anna, 2011). A gradual increase in the salt concentration (from 0 to $30 \mathrm{~g} \mathrm{NaCl} / \mathrm{L}$ ) has less impact on the COD removal in the aerobic system with salt-adapted microorganisms rather than the one with non-adapted biomass (Bassin et al., 2012).

With regard to the salty nature of textile wastewater, SBR was selected as the treatment system in the present study, the main purpose of which was to investigate the ability of the aerobic microorganisms of the activated sludge to remove dye from textile wastewater containing a high concentration of salts. So far, few studies have been done on treating wastewater containing dye under high saline conditions using the same treatment system.

\section{Materials and methods}

\subsection{Dye, sludge, and synthetic textile wastewater}

Remazol Brilliant Blue $\mathrm{R}\left(\mathrm{C}_{22} \mathrm{H}_{16} \mathrm{~N}_{2} \mathrm{Na}_{2} \mathrm{O}_{11} \mathrm{~S}_{3}\right)$ obtained from Iran Poplin textile factory was used as the model dye for all experiments. This is a reactive dye frequently used in the textile industry.

Activated sludge was obtained from the treatment plant of the pharmaceutical company Sobhan Darou Co. in Rasht, Iran because activated sludge microorganisms from the pharmaceutical factory were adapted with dyes and organic compounds.

At first, the synthetic wastewaters were made without adding salt to achieve basic adaptations with different concentrations of dye in microorganisms; synthetic wastewaters were made with dye concentrations of 125,250 , and $500 \mathrm{mg} / \mathrm{L}$. Then, after evaluating the COD removal efficiency of the first three synthetic wastewater treatments, synthetic wastewater samples with TDS concentrations of 1000,5000 , and $10,000 \mathrm{mg} / \mathrm{L}$ were made with a dye concentration of $125 \mathrm{mg} / \mathrm{L}$. $\mathrm{NH}_{4} \mathrm{Cl}$ and $\mathrm{KH}_{2} \mathrm{PO}_{4}$ were added as supplementary nutrients based on a COD/N/P ratio of approximately 100/5/1 for all samples.

\subsection{Equipment}

A magnetic stirrer set (Taksan Co., Iran), a 2000-mL beaker, and an air pump were used for the SBR treatment system. Other equipment used in this study included a BOD measuring device (Aqualytic Co., Germany), a digital scale with the precision of 0/0001 g (Sartorius Co., Germany) for measuring the dye and salt, an oven (DENA Co., Iran), an electrical furnace (Iran Khodsaz Co.) for MLSS and MLVSS tests, a spectrophotometer (WPA, S2100 Diode Array model, USA) for measuring absorption at a maximum visible wavelength of $570 \mathrm{~nm}$, and a portable device for measuring $\mathrm{pH}$ and TDS (ESICO Co., model 7200, USA).

All experiments were performed based on the standard methods for examining water and wastewater (APHA, 2005).

\subsection{SBR treatment process}

Based on the Sequencing Batch Reactor system, the treatment process was as follows: 
Table 1

Characteristics of real textile wastewater sample.

\begin{tabular}{|c|c|c|c|c|c|c|c|}
\hline Concentration & Absorption $(570 \mathrm{~nm})$ & $\mathrm{COD}(\mathrm{mg} / \mathrm{L})$ & $\mathrm{pH}(\mathrm{mg} / \mathrm{L})$ & $\mathrm{TDS}^{\mathrm{a}}(\mathrm{mg} / \mathrm{L})$ & $\mathrm{TSS}^{\mathrm{b}}(\mathrm{mg} / \mathrm{L})$ & Phosphorus (mg/L) & Nitrogen $(\mathrm{mg} / \mathrm{L})$ \\
\hline Textile wastewater & 1.387 & 140.80 & 7.50 & 1470 & 110 & 2.65 & 0 \\
\hline
\end{tabular}

The reactor was filled with $1500 \mathrm{~mL}$ synthetic wastewater and $500 \mathrm{~mL}$ activated sludge (filling stage). The magnetic stirrer and aeration pump were turned on to completely mix the synthetic wastewater and the aerobic microorganisms of the activated sludge for $22 \mathrm{~h}$ (reaction stage). Then, the magnetic stirrer and aeration pump were turned off to allow the suspended activated sludge to settle in the reactor (settling stage). Lastly, $1500 \mathrm{~mL}$ of treated wastewater was withdrawn from the reactor (withdrawal stage).

The treatment cycle was $24 \mathrm{~h}$ for each concentration, and the biological treatment process was repeated continuously for 7 days for all concentrations.

The temperature of the SBR system was $27 \pm 2{ }^{\circ} \mathrm{C}$.

\subsection{Effect of $p H$ on dye removal}

Studying dye removal efficiency in various $\mathrm{pH}$ values was another objective of the present research. The $\mathrm{pH}$ values of the samples used in this study were adjusted using $\mathrm{NaOH}$.

\subsection{Real textile wastewater}

Finally, real wastewater was collected from Iran Poplin textile factory for use in the study of dye and COD removal efficiency.

Real wastewater samples were transported to the laboratory and stored at $4{ }^{\circ} \mathrm{C}$ until their utilization.

As in the previously discussed process, $1500 \mathrm{~mL}$ of wastewater was mixed with $500 \mathrm{~mL}$ of activated sludge in the treatment reactor.

At first, the treatment process was performed on real textile wastewater which had a TDS concentration of $1470 \mathrm{mg} / \mathrm{L}$ for 7 days; then the TDS concentration of the wastewater was increased to $10,000 \mathrm{mg} / \mathrm{L}$ and the treatment process was repeated.

The analysis results of the real textile wastewater are displayed in Table 1.

\section{Results and discussion}

\subsection{Absorption, COD, and TDS parameters}

The test results of the studied parameters on raw and treated wastewaters are given in Tables 1 and 2 and Figures 1 and 2 .

As seen in Figure 2, the absorption amounts are in the same range with small changes during the 7 days of treatment. The range of the changes is very low at 0.002-0.004 in all concentrations on some days of treatment.

Also the procedure changes of absorption amounts and COD concentrations are obvious with regard to various dye and TDS
Table 2

$\mathrm{pH}$ changes in raw and treated wastewater samples (during 7 days of treatment).

\begin{tabular}{ll}
\hline Concentration $(\mathrm{mg} / \mathrm{L})$ & $\mathrm{pH}$ \\
\hline Raw $(125 \mathrm{mg} / \mathrm{L})^{\mathrm{a}}$ & 7.20 \\
Treated $(125 \mathrm{mg} / \mathrm{L})$ & $7.0 \pm 0.1$ \\
Raw $(250 \mathrm{mg} / \mathrm{L})^{\mathrm{b}}$ & 7.20 \\
Treated $(250 \mathrm{mg} / \mathrm{L})$ & $7.0 \pm 0.2$ \\
Raw $(500 \mathrm{mg} / \mathrm{L})^{\mathrm{c}}$ & 7 \\
Treated $(500 \mathrm{mg} / \mathrm{L})$ & $7.0 \pm 0.2$ \\
Raw $(125-\mathrm{TDS}=1000 \mathrm{mg} / \mathrm{L})^{\mathrm{d}}$ & 7 \\
Treated $(125-\mathrm{TDS}=1000 \mathrm{mg} / \mathrm{L})$ & $7.0 \pm 0.1$ \\
Raw $(125-\mathrm{TDS}=5000 \mathrm{mg} / \mathrm{L})^{\mathrm{e}}$ & 7 \\
Treated $(125-\mathrm{TDS}=5000 \mathrm{mg} / \mathrm{L})$ & $8.0 \pm 0.5$ \\
Raw $(125-\mathrm{TDS}=10,000 \mathrm{mg} / \mathrm{L})^{\mathrm{f}}$ & 7 \\
Treated $(125-\mathrm{TDS}=10,000 \mathrm{mg} / \mathrm{L})$ & 7.60 \\
Raw textile wastewater & 7.50 \\
Treated textile wastewater & $7.0 \pm 0.5$ \\
Raw $(\text { Textile W.-TDS }=10,000 \mathrm{mg} / \mathrm{L})^{\mathrm{h}}$ & 7.50 \\
Treated $($ Textile W.-TDS $=10,000 \mathrm{mg} / \mathrm{L})$ & 7.50
\end{tabular}

a Synthetic wastewater with dye concentration of $125 \mathrm{mg} / \mathrm{L}$.

b Synthetic wastewater with dye concentration of $250 \mathrm{mg} / \mathrm{L}$.

c Synthetic wastewater with dye concentration of $500 \mathrm{mg} / \mathrm{L}$.

d Synthetic wastewater with dye concentration of $125 \mathrm{mg} / \mathrm{L}$ and TDS concentration of $1000 \mathrm{mg} / \mathrm{L}$.

e Synthetic wastewater with dye concentration of $125 \mathrm{mg} / \mathrm{L}$ and TDS concentration of $5000 \mathrm{mg} / \mathrm{L}$.

${ }^{\mathrm{f}}$ Synthetic wastewater with dye concentration of $125 \mathrm{mg} / \mathrm{L}$ and TDS concentration of $10,000 \mathrm{mg} / \mathrm{L}$.

${ }^{\mathrm{g}}$ Real wastewater from textile factory.

${ }^{\mathrm{h}}$ Real wastewater from textile factory with TDS concentration of $10,000 \mathrm{mg} / \mathrm{L}$.

concentrations in raw and treated wastewater (Figs. 1 and 2); there is a logical connection between increasing the absorption amounts and increasing the COD concentrations in all samples.

The activated sludge microorganisms used in the SBR treatment reactor were treatment plant microorganisms from a pharmacy factory. Their adaptation with wastewater containing dye was predictable, and COD removal efficiency and the range of resultant absorption amounts confirmed this adaptation in all treated concentrations during the 7 days of treatment. The microorganisms' adaptation process was tested in each concentration for one week.

A study on removing RB-5 textile dye using activated sludge bacteria reported $100 \%$ dye removal after $48 \mathrm{~h}$ of starting treatment for synthetic wastewater with dye concentrations of 10 and $20 \mathrm{mg} / \mathrm{L}$. This result indicates that there was an adaptation background in microorganisms with similar conditions in synthetic wastewaters (Bahmani, Rezaei Kalantari, Joneidi Jafari, \& Javadi, 2009).

As seen in Figures 1 and 2, the absorption amounts and COD concentrations in raw and treated wastewater with a dye concentration of $125 \mathrm{mg} / \mathrm{L}$ and a TDS concentration of 


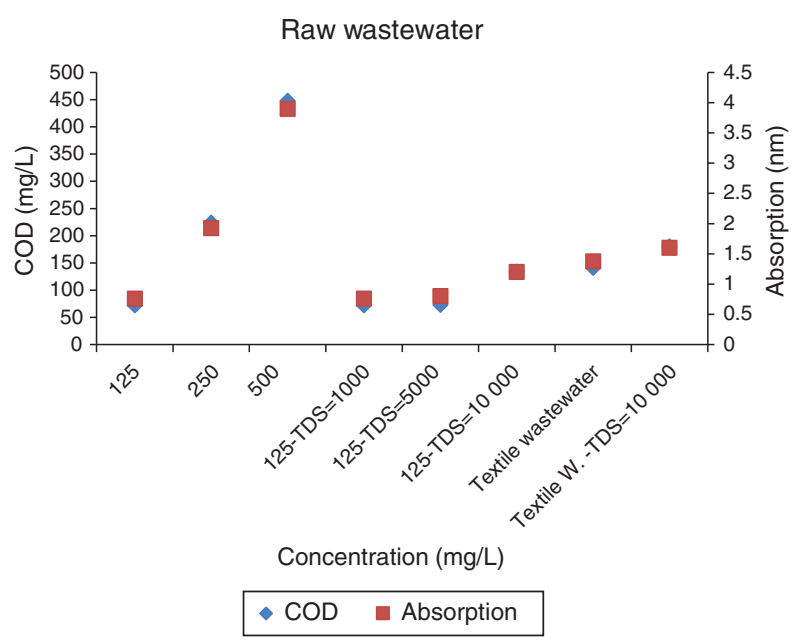

Fig. 1. Changes in COD concentrations and absorption amounts in 8 samples of raw wastewater. $125 \mathrm{mg} / \mathrm{L}$ : synthetic wastewater with dye concentration of $125 \mathrm{mg} / \mathrm{L} ; 250 \mathrm{mg} / \mathrm{L}$ : synthetic wastewater with dye concentration of $250 \mathrm{mg} / \mathrm{L}$; $500 \mathrm{mg} / \mathrm{L}$ : synthetic wastewater with dye concentration of $500 \mathrm{mg} / \mathrm{L} ; 125-$ TDS $=1000 \mathrm{mg} / \mathrm{L}$ : synthetic wastewater with dye concentration of $125 \mathrm{mg} / \mathrm{L}$ and TDS concentration of $1000 \mathrm{mg} / \mathrm{L} ; 125-\mathrm{TDS}=5000 \mathrm{mg} / \mathrm{L}$ : synthetic wastewater with dye concentration of $125 \mathrm{mg} / \mathrm{L}$ and TDS concentration of $5000 \mathrm{mg} / \mathrm{L} ; 125$ $\mathrm{TDS}=10,000 \mathrm{mg} / \mathrm{L}$ : synthetic wastewater with dye concentration of $125 \mathrm{mg} / \mathrm{L}$ and TDS concentration of $10,000 \mathrm{mg} / \mathrm{L}$; Textile Wastewater: real wastewater from textile factory; Textile W.-TDS $=10,000 \mathrm{mg} / \mathrm{L}$ : real wastewater from textile factory with TDS concentration of $10,000 \mathrm{mg} / \mathrm{L}$.

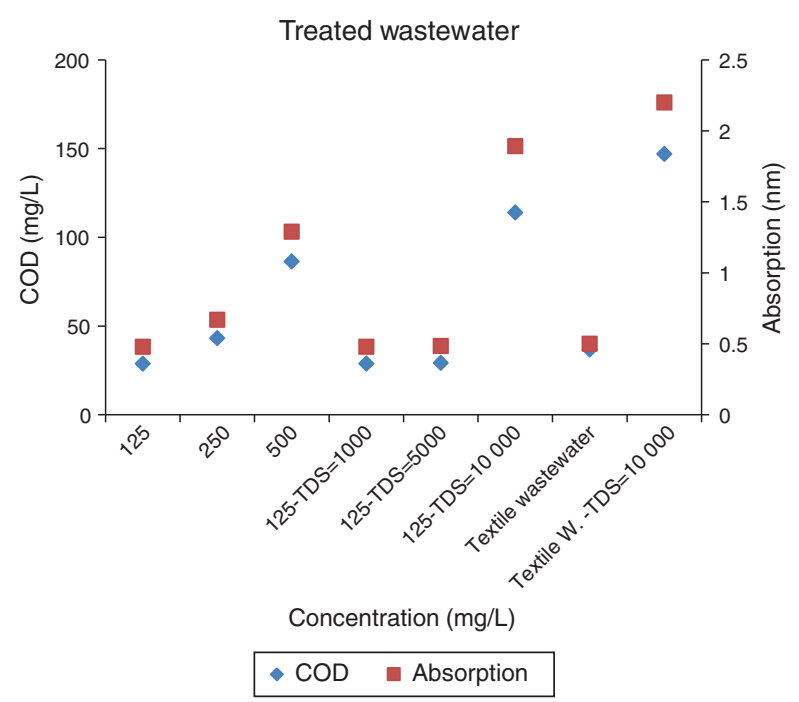

Fig. 2. Changes in COD concentrations and absorption amounts in 8 samples of treated wastewater. $125 \mathrm{mg} / \mathrm{L}$ : synthetic wastewater with dye concentration of $125 \mathrm{mg} / \mathrm{L} ; 250 \mathrm{mg} / \mathrm{L}$ : synthetic wastewater with dye concentration of $250 \mathrm{mg} / \mathrm{L}$; $500 \mathrm{mg} / \mathrm{L}$ : synthetic wastewater with dye concentration of $500 \mathrm{mg} / \mathrm{L} ; 125$ TDS $=1000 \mathrm{mg} / \mathrm{L}$ : synthetic wastewater with dye concentration of $125 \mathrm{mg} / \mathrm{L}$ and TDS concentration of $1000 \mathrm{mg} / \mathrm{L} ; 125-\mathrm{TDS}=5000 \mathrm{mg} / \mathrm{L}$ : synthetic wastewater with dye concentration of $125 \mathrm{mg} / \mathrm{L}$ and TDS concentration of $5000 \mathrm{mg} / \mathrm{L} ; 125-$ TDS $=10,000 \mathrm{mg} / \mathrm{L}$ : synthetic wastewater with dye concentration of $125 \mathrm{mg} / \mathrm{L}$ and TDS concentration of $10,000 \mathrm{mg} / \mathrm{L}$; Textile Wastewater: real wastewater from textile factory; Textile W.-TDS $=10,000 \mathrm{mg} / \mathrm{L}$ : real wastewater from textile factory with TDS concentration of $10,000 \mathrm{mg} / \mathrm{L}$.
$1000 \mathrm{mg} / \mathrm{L}$ are the same as those in the wastewater with a dye concentration of $125 \mathrm{mg} / \mathrm{L}$ and low salt. This result indicated that a TDS concentration of $1000 \mathrm{mg} / \mathrm{L}$ did not affect the treatment efficiency of microorganisms.

In the wastewater with a dye concentration of $125 \mathrm{mg} / \mathrm{L}$ and a salt concentration of $5000 \mathrm{mg} / \mathrm{L}$, the percentage of dye removal was $59.44 \%$. Comparing this result with that related to the sample with the same dye concentration but very low salt $(60 \%$ dye removal) proves the continuous adaptation of microorganisms in salt concentrations of $5000 \mathrm{mg} / \mathrm{L}$.

According to Reid's findings, microorganisms can adapt and survive in specific amounts of salt increasing (up to $5000 \mathrm{mg} / \mathrm{L}$ ) by aggregating their cells and through physiological changes (Reid, Liu, \& Judd, 2006).

The results of a research related to saline shock on activated sludge indicated that the tolerance threshold in activated sludge microorganisms is different when they encounter saline wastewater; some of them resist salt concentrations up to $5000 \mathrm{mg} / \mathrm{L}$ and some of them up to $10,000 \mathrm{mg} / \mathrm{L}$ (Salvadó et al., 2001).

Main changes happened in treatment efficiency when the TDS concentration of the synthetic wastewater increased to $10,000 \mathrm{mg} / \mathrm{L}$. As seen in Figure 2, increasing the concentration of TDS led to an increase in COD concentration in wastewater and decreased COD removal efficiency to $14.92 \%$.

In a study about the biological treatment of tannery wastewater using activated sludge microorganisms, a reduction in COD and BOD removal efficiencies became obvious when the biological treatment process took place in salt concentrations higher than $8000 \mathrm{mg} / \mathrm{L}$ (Sivaprakasam, Mahadevan, Sekar, \& Rajakumar, 2008).

In real textile wastewater with a TDS concentration of about $1500 \mathrm{mg} / \mathrm{L}$, the dye removal percentage obtained $(73.86 \%)$ was as expected.

Again, in the last sample with a TDS concentration increased to $10,000 \mathrm{mg} / \mathrm{L}$, the COD concentration increased in the treated wastewater; thus, the COD removal percentage, which was $18.33 \%$, decreased, contrary to the similar sample with low salt concentration (real textile wastewater).

According to Reid's study on the effects of high salinity on activated sludge systems and membrane permeability, if the salt concentration in raw wastewater increases to more than $5000 \mathrm{mg} / \mathrm{L}$, saline shock occurs in the biological treatment system and causes turbidity. As a result, colloidal material and suspended matter increase turbidity which is positively related to chloride levels as well as protein. An increase in TDS concentration causes increased protein solubility in biological systems; on the other hand, protein increases the floc's negative surface charge which leads to a decrease in mechanical strength between the flocs, and so increases colloidal material (Reid et al., 2006).

As stated in different reports, saline shock refers to increasing salt concentrations more than $5000 \mathrm{mg} / \mathrm{L}$ which affects COD and BOD removal as well as sludge coagulation properties and settlement. When a biological treatment system is used for wastewater with high salinity, the reason for decreasing COD removal is plasmolysis of the bacterial cells under the effects of salt, which leads to their loss of activity. Therefore, it can directly affect treatment efficiency (Kargi \& Dincer, 1996). 


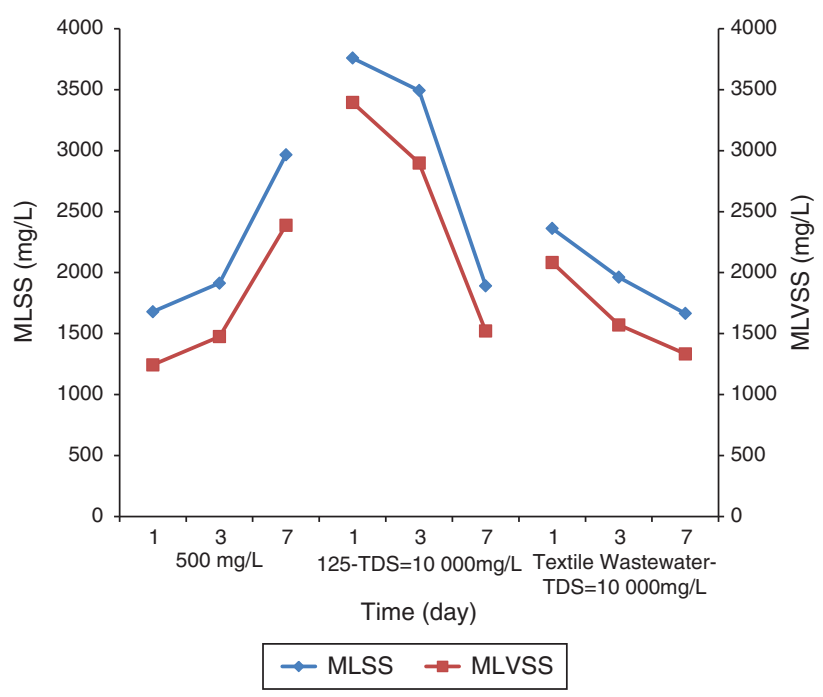

Fig. 3. Changes in MLSS and MLVSS concentrations during the treatment of 3 samples: 1 - synthetic wastewater containing a dye concentration of $500 \mathrm{mg} / \mathrm{L}$ and low salt; 2 - synthetic wastewater containing a dye concentration of $125 \mathrm{mg} / \mathrm{L}$ and TDS concentration of $10,000 \mathrm{mg} / \mathrm{L} ; 3$ - real textile wastewater with a TDS concentration of $10,000 \mathrm{mg} / \mathrm{L} .500 \mathrm{mg} / \mathrm{L}$ : synthetic wastewater with dye concentration of $500 \mathrm{mg} / \mathrm{L} ; 125-\mathrm{TDS}=10,000 \mathrm{mg} / \mathrm{L}$ : synthetic wastewater with dye concentration of $125 \mathrm{mg} / \mathrm{L}$ and TDS concentration of $10,000 \mathrm{mg} / \mathrm{L}$; Textile Wastewater-TDS $=10,000 \mathrm{mg} / \mathrm{L}$ : real wastewater from textile factory with TDS concentration of $10,000 \mathrm{mg} / \mathrm{L}$; MLSS: mixed liquor suspended solids; MLVSS: mixed liquor volatile suspended solids.

It has also been proven that high concentrations of

$\mathrm{NaCl}$ in an activated sludge system cause the destruction of the microorganisms' cell walls and, eventually, disorder in the biological treatment (Hamoda \& Al-Attar, 1995).

In the present research, the microorganisms adapted, and so COD removal continued at TDS concentrations of $1000 \mathrm{mg} / \mathrm{L}$ and even $5000 \mathrm{mg} / \mathrm{L}$. However, a very small change occurred in COD removal when the TDS concentration of raw wastewater was raised to $5000 \mathrm{mg} / \mathrm{L}$; this level of salt concentration represents the starting point of alternations in the function of activated sludge microorganisms.

\subsection{MLSS and MLVSS parameters}

To evaluate the microbial population and growth of activated sludge microorganisms, MLSS and MLVSS concentrations were measured throughout the 7 days of treatment. The results for the three selected samples $((500 \mathrm{mg} / \mathrm{L}),(125-\mathrm{TDS}=10,000 \mathrm{mg} / \mathrm{L})$, and (Textile Wastewater-TDS $=10,000 \mathrm{mg} / \mathrm{L})$ ) are given in Figure 3.

In this figure, the graph related to synthetic wastewater with a dye concentration of $500 \mathrm{mg} / \mathrm{L}$ and COD concentration of $448 \mathrm{mg} / \mathrm{L}$ (in raw wastewater) represents the appropriate living conditions for microorganisms, because the graph is ascending (microbial population has grown). High efficiency has been reported for COD removal $(80.71 \%)$ in this concentration. Microorganisms of activated sludge degrade the dyes by producing many enzymes such as laccase, manganese peroxidase, among others. Manganese peroxidase is capable of decoloring Remazol Brilliant Blue R. Therefore, under aerobic conditions the microorganisms change dyes to organic materials and water. It leads to an increase of MLSS and, as a result, an increase of dye degradation by more microbial biomass (Gowri, Vijayaraghavan, \& Meenambigai, 2014).

The descending procedure of MLSS and MLVSS graph for synthetic wastewater with a dye concentration of $125 \mathrm{mg} / \mathrm{L}$, TDS concentration of $10,000 \mathrm{mg} / \mathrm{L}$, and COD concentration of $134 \mathrm{mg} / \mathrm{L}$ indicates that increasing the salt concentration caused the microorganism population to decrease over 7 days.

As mentioned, the changing characteristics of the sludge which was treating the wastewater and the decreasing microorganism population are conditions that arise from high salinity (especially levels over $5000 \mathrm{mg} / \mathrm{L}$ ).

In the third sample, the MLSS and MLVSS concentrations are related to the real textile wastewater sample with a TDS concentration of $10,000 \mathrm{mg} / \mathrm{L}$ that represents a decreasing microorganism population during the treatment days.

Results indicated that high salt concentrations lead to unavoidable impacts on MLSS concentrations as a result of changes in the characteristics of activated sludge (Reid et al., 2006).

\section{3. $p H$ parameter}

Studying dye removal efficiency when the $\mathrm{pH}$ of the samples was changed was one objective of this research. According to Table 2, for wastewater with a dye concentration of $125 \mathrm{mg} / \mathrm{L}$ and a TDS concentration of $5000 \mathrm{mg} / \mathrm{L}$ and real textile wastewater, the treating processes were accomplished in a $\mathrm{pH}$ range of 7.5-8.5 for the first sample and 6.5-7.5 for the second sample during treatment days. The results showed no significant changes in the absorption amounts and COD removal efficiencies in the days that $\mathrm{pH}$ changes were applied; the reason for this is related to the range of microorganism activity with regard to the environment $\mathrm{pH}$.

According to different resources, the optimum $\mathrm{pH}$ for an activated sludge system is 6.50-8.50 (Kalmi, Parshetti, Jadhav, \& Govindwar, 2007; Ogugbue \& Sawidis, 2011; Rao \& Prasad, 2010). Microorganisms try to maintain their environmental pH near a neutral range by consuming energy. They have a special external structure which protects them. The minimum to maximum $\mathrm{pH}$ resistance range in activated sludge microorganisms is 6.50-8.50 (Barati, 2007).

\section{Conclusions}

The main purpose of this study was to investigate the ability of aerobic microorganisms of an SBR treatment system to remove COD from high saline textile wastewater. The activated sludge microorganisms could tolerate high salt concentrations and remove $60 \%$ of Brilliant Blue R dye from wastewater at a TDS concentration of $5000 \mathrm{mg} / \mathrm{L}$; thus, SBR as a cost effective treatment system can be used for decolorization of textile wastewater even in saline conditions. 


\section{Conflict of interest}

The authors have no conflicts of interest to declare.

\section{References}

Anjaneyulu, Y., Chary, N. S., \& Raj, D. S. S. (2005). Decolourization of industrial effluents - Available methods and emerging technologies - A review. Reviews in Environmental Science and Bio/Technology, 4(4), 245-273.

APHA. (2005). Standard methods for the examination of water and wastewater. New York: American Public Health Association.

Bahmani, P., Rezaei Kalantari, R., Joneidi Jafari, A., \& Javadi, Z. (2009). Surveying RB-5 azo dye removal from synthetic wastewater by biological method. In 12th Natl Conf. on Environ. Health of Iran, Vol. 12 (pp. 212-221).

Banat, I. M., Nigam, P., Singh, D., \& Marchant, R. (1996). Microbial decolorization of textile-dyecontaining effluents: A review. Bioresource Technology, 58(3), 217-227.

Barati, B. (2007). Microbiology laboratory. pp. 42-43. Tehran, Iran: Ghalam Press.

Bassin, J. P., Dezotti, M., \& Sant'Anna, G. L. (2011). Nitrification of industrial and domestic saline wastewaters in moving bed biofilm reactor and sequencing batch reactor. Journal of Hazardous Materials, 185(1), 242-248.

Bassin, J. P., Kleerebezem, R., Muyzer, G., Rosado, A. S., van Loosdrecht, M. C., \& Dezotti, M. (2012). Effect of different salt adaptation strategies on the microbial diversity, activity, and settling of nitrifying sludge in sequencing batch reactors. Applied Microbiology and Biotechnology, 93(3), 1281-1294.

Chaeibakhsh Langroodi, N., \& Abedinzadeh, N. (2004). Surveying production process and pollutants of existing units in Guilan industrial estates. pp. 33-35. Iran: Guilan Environmental Research Institute.

Dodangeh, M., \& Gharanjig, K. (2012). A review on synthesis, properties and application of advanced naphthalimide dyes. Journal of Advance Materials Novel Coatings, 2, 13-30.

Hamoda, M. F., \& Al-Attar, I. M. S. (1995). Effects of high sodium chloride concentrations on activated sludge treatment. Water Science and Technology, 31(9), 61-72.

Javaid, R., Qazi, U. Y., \& Kawasaki, S. I. (2016). Highly efficient decomposition of Remazol Brilliant Blue R using tubular reactor coated with thin layer of PdO. Journal of Environmental Management, 180, 551-556.

Kalmi, S. D., Parshetti, G. K., Jadhav, S. U., \& Govindwar, S. P. (2007). Biodegradation of benzedine based Direct Blue-6 by Pseudomonas desmolyicum NCIM 2112. Bioresource Technology, 98, 1405-1410.

Kargi, F., \& Dincer, A. R. (1996). Effect of salt concentration on biological treatment of saline wastewater by fed-batch operation. Enzyme and Microbial Technology, 19(7), 529-537.

Khouni, I., Marrot, B., \& Amar, R. B. (2012). Treatment of reconstituted textile wastewater containing a reactive dye in an aerobic sequencing batch reactor using a novel bacterial consortium. Separation and Purification Technology, 87, 110-119.

Mace, S., \& Mata-Alvarez, J. (2002). Utilization of SBR technology for wastewater treatment: An overview. Industrial \& Engineering Chemistry Research, 41(23), 5539-5553.

Mahmoud, T. A., \& Davis, W. B. (1979). The effect of salinity on the removal of some aliphatic ketones. Environmental Engineering Division, Texas Engineering Experiment Station.
Mesquita, D. P., Amaral, A. L., Ferreira, E. C., \& Coelho, M. A. (2009). Study of saline wastewater influence on activated sludge flocs through automated image analysis. Journal of Chemical Technology and Biotechnology, 84(4), 554-560.

Mohan, S. V., Rao, N. C., Prasad, K. K., Madhavi, B. T. V., \& Sharma, P. N. (2005). Treatment of complex chemical wastewater in a sequencing batch reactor (SBR) with an aerobic suspended growth configuration. Process Biochemistry, 40(5), 1501-1508.

Nigam, P., Banat, I. M., Singh, D., \& Marchant, R. (1996). Microbial process for the decolorization of textile effluent containing azo, diazo and reactive dyes. Process Biochemistry, 31(5), 435-442.

Ogugbue, C. J., \& Sawidis, T. (2011). Bioremediation and detoxification of synthetic wastewater containing triarylmethane dyes by Aeromonas hydrophila isolated from industrial effluent. Biotechnology Research International, 10, 4061-4079.

Quan, X., Zhang, X., \& Xu, H. (2015). In-situ formation and immobilization of biogenic nanopalladium into anaerobic granular sludge enhances azo dyes degradation. Water Research, 78, 74-83.

Rao, S., \& Prasad, k. (2010). Decolonization of Direct Black-17 by bacteria Bioresource Technology, 98, 2168-2171.

Reid, E., Liu, X., \& Judd, S. J. (2006). Effect of high salinity on activated sludge characteristics and membrane permeability in an immersed membrane bioreactor. Journal of Membrane Science, 283(1), 164-171.

Salvadó, H., Mas, M., Menéndez, S., \& Gracia, M. P. (2001). Effects of shock loads of salt on protozoan communities of activated sludge. Acta Protozoologica, 40(3), 177-185.

Gowri, R. S., Vijayaraghavan, R., \& Meenambigai, P. (2014). Microbial degradation of reactive dyes - A review. International Journal Current Microbiology and Applied Sciences, 3, 421-436.

Sirianuntapiboon, S., \& Maneewon, S. (2012). Effects of bio-sludge concentration and dilution rate on the efficiency of sequencing batch reactor (SBR) system for textile wastewater treatment. EnvironmentAsia, 5(2), 36-52.

Sivaprakasam, S., Mahadevan, S., Sekar, S., \& Rajakumar, S. (2008). Biological treatment of tannery wastewater by using salt-tolerant bacterial strains. Microbial Cell Factories, 7(1), 15

Soares, P. A., Souza, R., Soler, J., Silva, T. F., Souza, S. M. G. U., Boaventura, R. A., et al. (2017). Remediation of a synthetic textile wastewater from polyester-cotton dyeing combining biological and photochemical oxidation processes. Separation and Purification Technology, 172, 450-462.

Vandevivere, P. C., Bianchi, R., \& Verstraete, W. (1998). Treatment and reuse of wastewater from the textile wet-processing industry: Review of emerging technologies. Journal of Chemical Technology and Biotechnology, 72(4), 289-302.

Woolard, C. R., \& Irvine, R. L. (1995). Treatment of hypersaline wastewater in the sequencing batch reactor. Water Research, 29(4), 1159-1168.

Xiao, Y., \& Roberts, D. J. (2010). A review of anaerobic treatment of saline wastewater. Environmental Technology, 31(8-9), 1025-1043.

Yurtsever, A., Calimlioglu, B., Görür, M., Çınar, Ö., \& Sahinkaya, E. (2016). Effect of $\mathrm{NaCl}$ concentration on the performance of sequential anaerobic and aerobic membrane bioreactors treating textile wastewater. Chemical Engineering Journal, 287, 456-465. 